\title{
The Impact of Covid-19 Pandemic and Social Distancing on Banks' Asset Quality: An International Evidence
}

\author{
Nader Alber and Mohamed Dabour
}

\section{ABSTRACT}

This paper aims at testing the significance of each of Covid-19 pandemic and social distancing on banks' asset quality, using a sample of 30 banks representing 10 countries according to GMM technique. Data have been collected from the World Health Organization during 2020. The research covers 10 countries (Egypt; Saudi Arabia; Indonesia; Germany; France; Russia; India; Mexico; South Korea and Nigeria) where 3 banks have been investigated from each country.

Results indicate that banks' asset quality measured by Average change of nonperforming loans ratio seems to be sensitive to Covid-19 spread, measured by Average cases of COVID-19. Besides, findings support the effect of social distancing, measured by each of average staying at residential and average social distancing for retail-recreation. It's important to pinpoint that results do not support the effect of each of average deaths of Covid-19 and average social distancing for workplaces, residential, grocery pharmacy, parks and transit stations.

Keywords: asset quality; banking performance; Covid-19 pandemic; industry effect; social distancing.

\section{INTRODUCTION}

All crises have financial consequences that may become visible at different levels: the state, the corporates, the households and eventually the financial sector itself. Then the real economy and banks may be heavily affected and non-performing loans (NPL) levels will eventually rise in the aftermath of such crises. So, banks have to deal with the increased level of NPLs in a way that protect their own viability (Kasinger et al., 2021).

NPLs are appearing when the amount of repayment falls below the contracted value carried on bank's balance sheet. When this happens, loan loss provisions (LLPs) are made, as accounting deduction. A key economic consequence of insufficient LLPs and the persistence of NPLs on bank balance sheets is the combined threat of a "capital crunch" with a "credit crunch" (Hoshi \& Kashyap 2009; Hoshi \& Kashyap, 2008). The prominence of NPLs in today's crises is nothing new. On the contrary, NPLs represent recurring features of economic and banking crises.

In brief, this study tries to investigate the impact of Covid-19 pandemic and social distancing on banks' asset quality. After this introduction, section 2 illustrates the research problem and section 3 reviews research literature. Section 4 explains how to measure research variables and illustrates how to test the hypotheses. Section 5 is for presenting results and discussing how these results answer research questions. Section 6 summarizes the paper and provide remarks about conclusions.
Submitted : September 25, 2021

Published : November 06, 2021

ISSN: 2507-1076

DOI: $10.24018 / \mathrm{ejbmr} .2021 .6 .6 .1122$

Nader Alber*

Professor of Finance, Faculty of Business;

Ain Shams University, Egypt.

(e-mail: naderalberfanous ${ }^{@}$ yahoo.com)

Mohamed Dabour

$\mathrm{PhD}$ candidate, Faculty of Business, Ain

Shams University, Egypt.

(e-mail: dabor_creative@yahoo.com)

*Corresponding Author

\section{RESEARCH PROBLEM}

During 2020, Coronavirus spread has grown rapidly, measured by average deaths and average cases. Consequently, social distancing has been affected. The following figures illustrate these changes in 10 countries, as follows:

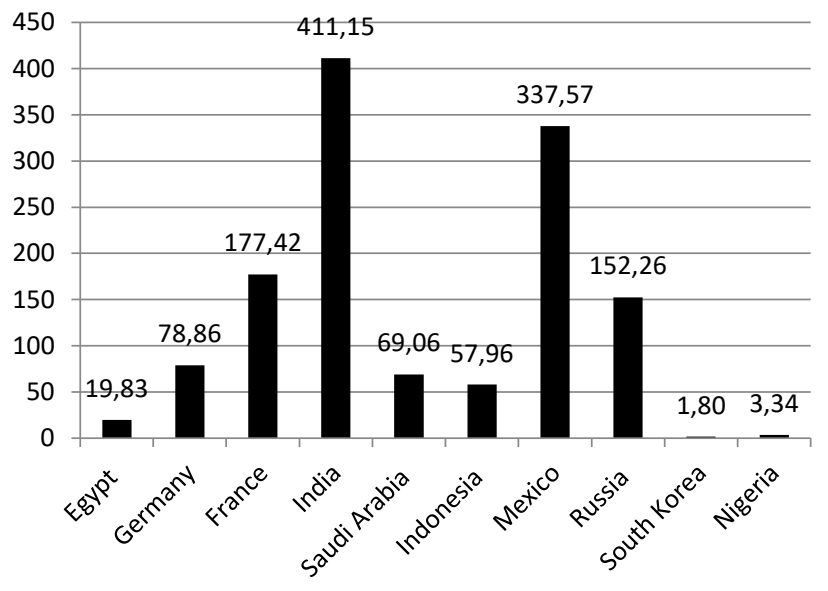

Fig. 1. Average Deaths of Covid-19 per 100,000. 


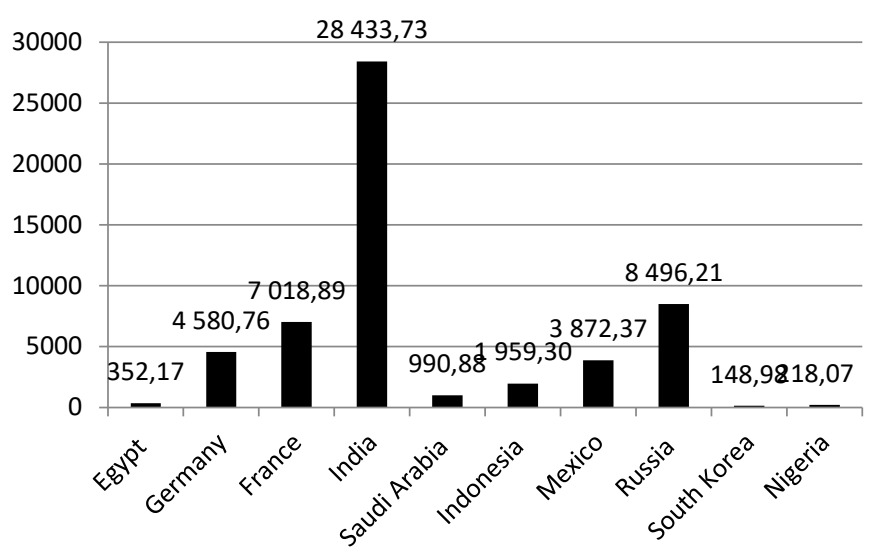

Fig. 2. Average Cases of Covid-19 per 100,000.

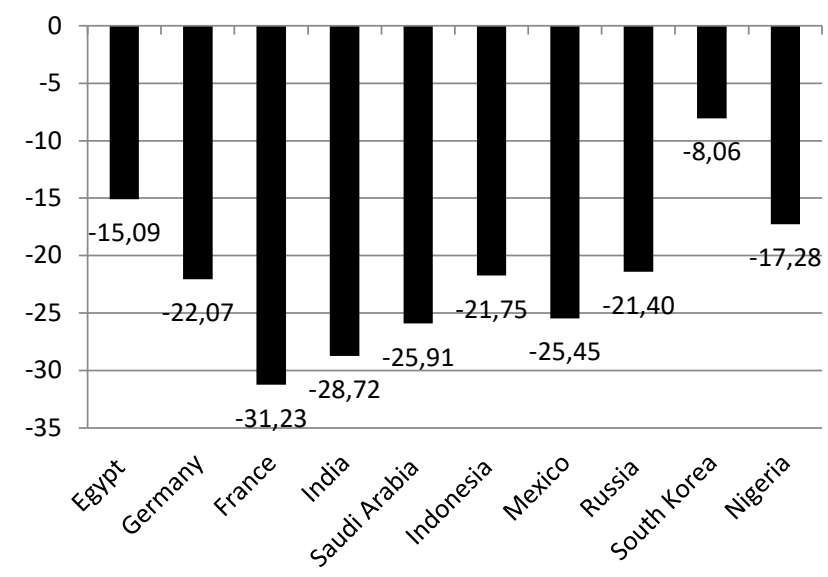

Fig. 3. Annual Average of Social Distancing for Workplaces.

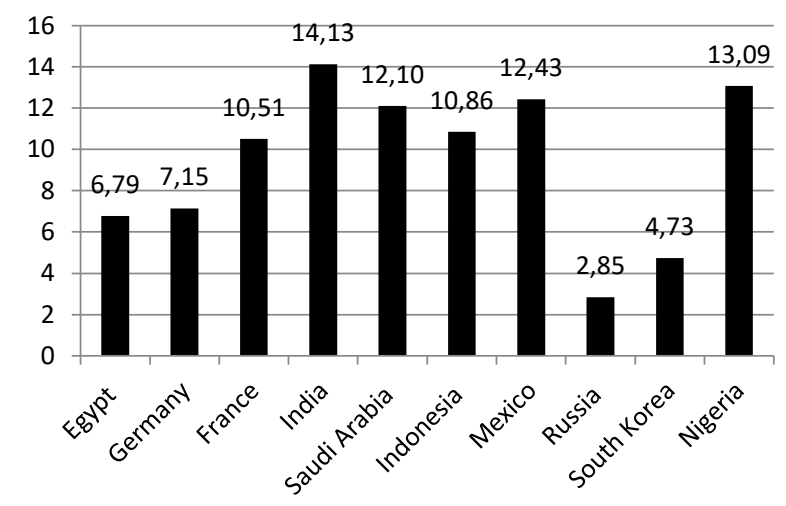

Fig. 4. Annual Average of Staying at Residential.

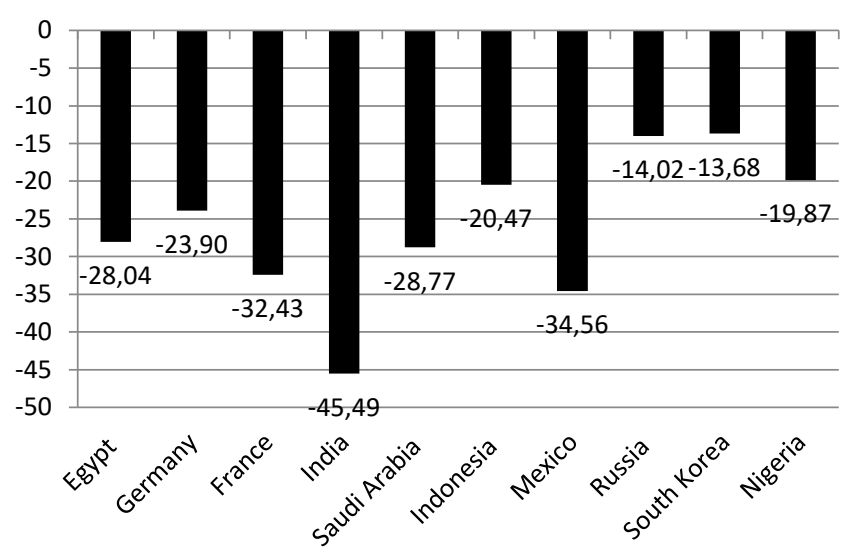

Fig. 5. Annual Average of Social Distancing for Retail-Recreation.

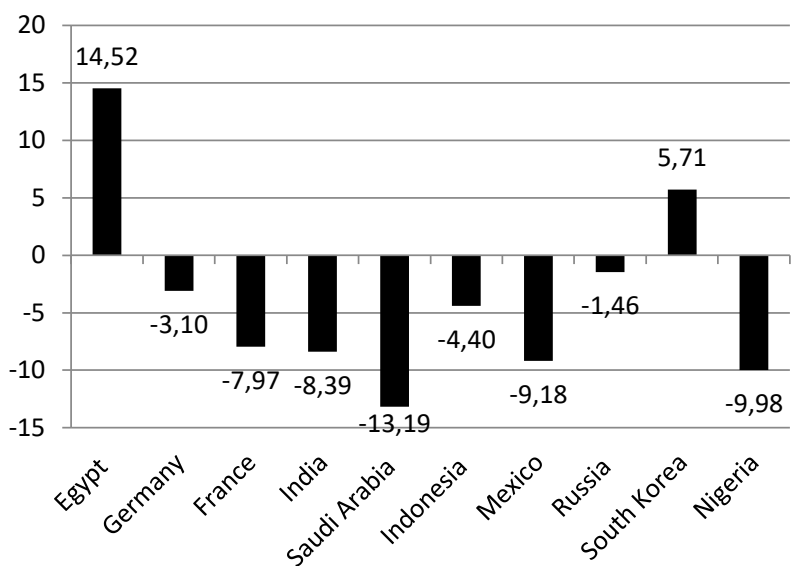

Fig. 6. Annual Average of Social Distancing for Grocery Pharmacy.

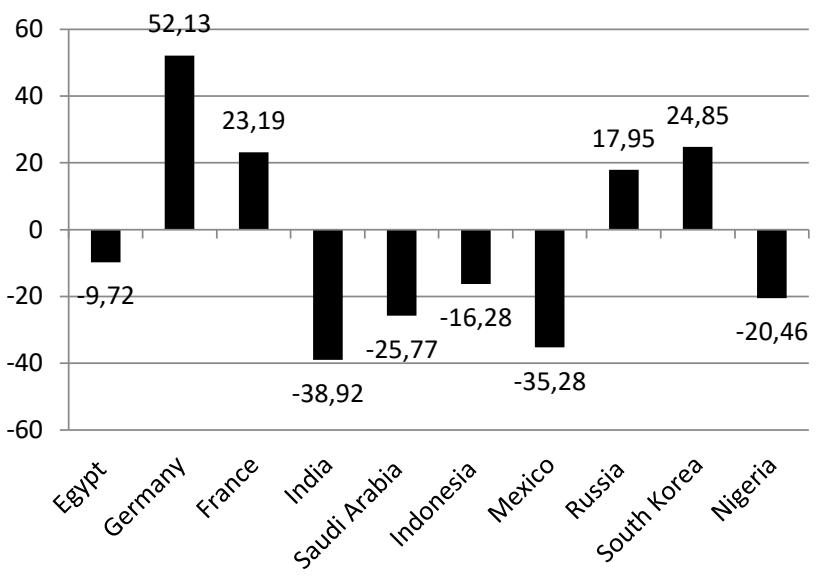

Fig. 7. Annual Average of Social Distancing for Parks

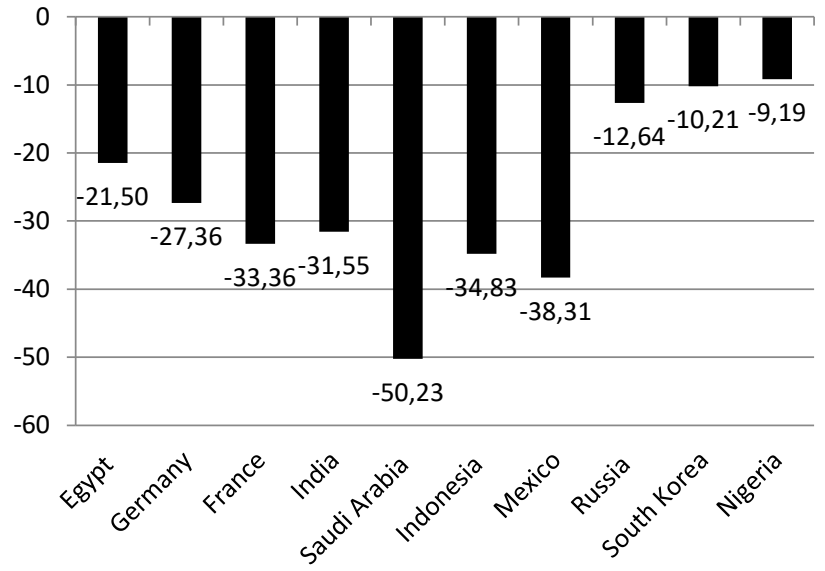

Fig. 8. Annual Average of Social Distancing for Transit Stations.

This paper attempts to address the following questions:

1. Is there an impact of Covid-19 pandemic on banks' asset quality?

2. Is there an impact of social distancing (due to Covid-19 pandemic) on banks' asset quality?

\section{LITERATURE REVIEW}

Many scholars have investigated the stock market response to Covid-19 spread, while the banking performance especially in the aspects of asset quality needs to be more elaborated. For example, Alber (2020a) investigates the effects of Coronavirus spread on the stock markets of the worst 6 countries, while Alber (2020b) 
addresses these effects for the European stock markets. Moreover, Alber \& Saleh (2020) attempts to investigate these effects in the stock markets of GCC countries. Besides, Arafa \& Alber (2020) indicates that stock market returns in the MENA countries tend to be negatively affected Coronavirus cumulative deaths and Coronavirus new deaths during.

Regarding the effect of Covid-19 on "banking asset quality", there is no common definition for NPL but in common level, an NPL is a loan where a borrower is not making repayments in accordance with contractual obligations. However, the detailed definition of an NPL is not universal (Angklomkliew, George \& Packer, 2009). Besides, NPL is defined as a sum of borrowed money upon which the debtor has not made his or her scheduled payments for at least 90 days (Cortavarria et al., 2000).

Banks response to Covid-19 spread should be more elaborated, where banks' asset quality seems to be sensitive to social distancing due to Covid-19 spread. Haselmann \& Troger (2021) addresses three characteristics that are unique to the present the current pandemic, as follows: a) extraordinary differences in the pandemic effects across industry sectors. b) an unprecedented level of government intervention and fiscal support at the industry level. c) a high level of expectation ambiguity as to the longer-term real sector consequences, due to serial lockdowns.

It's important to pinpoint the diverse consequences on many industries which are caused by a policy of lockdowns that are rather harmful in many industries, such as tourism, restaurants and culture, while pushing the business model up in other industries. E-commerce, communication, information technology in general and pharmaceuticals are examples of industries that get benefits from the Covid-19 (Gourinchas et al., 2021).

Forces that can make NPLs resolution after the Covid-19 events are different from that after the 2008- 2012 crisis. Anyway, a sound management of NPL should consider the following:

1. Transparency providing information basis for both sellers and buyers, leading to decrease the bid-ask-spread and enabling better trading decisions, allowing the free entry of intermediaries as trading platforms or market makers, hence reaching market efficiency by motivating uses of innovative technology and trading models.

2. A central data hub, which will allow banks and practitioners to improve the accuracy of NPLs valuation and then reduce the negative consequences of overdue loan loss recognition (Dilba \& Denis, 2020).

3. A robust and well-improved secondary loan market, contributing for the stability of the banking sector in state and improving the loan quality information that is available for customers (Gourinchas et al., 2020).

Kasinger et al. (2021) indicates that total bank capital seems to be large enough to ingest potential NPL losses, even in an inverse scenario. Real sector disorders affect the banking sector indirectly, by weakening companies' business models, and by reducing household capital, leading to a weaken bank's loan book, none performing, and lowering the bank's economic capital.

Regarding social distancing due to Covid-19, Alber \& Dabour (2020) investigates the opportunities of growth under restrictions of social distancing for FinTech. Results indicate that social distancing may affect digital payments for retail and recreation, grocery and pharmacy, transit stations and workplaces, without any evidence about significant effects for parks and residentials. Besides, stock market winners and losers have been addressed, where Alber \& Refaat (2021) investigate the effects of Coronavirus spread on the Egyptian Exchange. Results support the significant negative industry effects for each of Food, Beverages and Tobacco and Health Care \& Pharmaceuticals (as losers) and the significant positive industry effects for each of Energy \& Support Services, Shipping \& Transportation Services and Trade \& Distributors (as winners).

Accordingly, Covid-19 has caused increase in many sectors failures, raising the risk to the banking sector through a rise in non-performing loans (Gourinchas et. al., 2020). Governments applied a package of precautionary measures and fiscal policies, such as tax deferrals, direct cash transfers, government guaranteed loans, and equity-like injections to provide support to struggling companies (Mongey et al., 2020; Moreno et al., 2020). According to (Wagdi \& Rabie, 2021), there are impact of Covid-19 pandemic on business activities, and consequential this may affect banking asset quality.

To our knowledge, literature hasn't concern with the effect of both of Covid-19 spread and social distancing on banks' asset quality. This is why we try to work on this research gap.

\section{MEASURING VARIABLES AND DEVELOPING HYPOTHESES}

This paper aims at testing the significance of each of Covid-19 pandemic and social distancing on banks' asset quality. This has been conducted using a sample of 30 banks representing 10 countries according to GMM technique. Data have been collected from the World Health Organization during 2020. The research covers 10 countries (Egypt; Saudi Arabia; Indonesia; Germany; France; Russia; India; Mexico; South Korea and Nigeria) where 3 banks have been investigated from each country. Data about Coronavirus are obtained from: https://www.worldometers.info/coronavirus and research variables are calculated as follows:

TABLE I: THE RESEARCH VARIABLES

\begin{tabular}{ccc}
\multicolumn{3}{c}{ TABLE I: THE RESEARCH VARIABLES } \\
\hline Variable & Sign & Type \\
\hline Average cases of Covid-19 per 100,000 & CAS & Independent \\
Average deaths of Covid-19 per 100,000 & DEA & Independent \\
Average social distancing for workplaces & WOR & Independent \\
Average staying at residential & RES & Independent \\
Average social distancing for retail-recreation & RET & Independent \\
Average social distancing for grocery pharmacy & PHA & Independent \\
Average social distancing for Parks & PAR & Independent \\
Average social distancing for transit stations & TRA & Independent \\
Average change of nonperforming loans ratio & NPL & Dependent
\end{tabular}

This paper aims at testing the following two hypotheses:

1. There is no significant impact of COVID-19 pandemic on banks' asset quality.

2. There is no significant impact of social distancing (due to COVID-19) on banks' asset quality. 
Regarding the above-shown hypotheses, the null hypothesis $\mathrm{H} 0$ states that, $\beta=0$, while the alternative hypothesis $\mathrm{H} 1$ states that, $\beta \neq 0$

$$
\begin{aligned}
\mathrm{NPL}= & \alpha+\beta 1 \mathrm{CAS}+\beta 2 \mathrm{DEA}+\beta 3 \mathrm{WOR}+\beta 4 \mathrm{RES}+\beta 5 \\
& \mathrm{RET}+\beta 6 \mathrm{PHA}+\beta 7 \mathrm{PAR}+\beta 8 \mathrm{TRA}+\varepsilon
\end{aligned}
$$

Regarding each hypothesis, the null hypothesis H0 states that $\beta=0$, while the alternative one $H 1$ states that $\beta \neq 0$.

\section{Descriptive Statistics AND TESTING HyPotheses}

Tables (2) illustrates the descriptive statistics variables for the research variables, as in Table II.

Regarding normality, Jarque-Bera values indicate that all independent variables are normally distributed at a P-value of 0.10 .

Tables III shows the correlation coefficients between the research variables, as in Table III.

Regarding the problem of autocorrelation, correlation coefficients indicate that it may exist in case of having RET and DEA, RET and WOR or TRA and WOR in the same model, where correlation coefficients aren't whining -0.7 to 0.7 .

This paper aims at testing the significance of each of Covid-19 pandemic and social distancing on banks' asset quality, using a sample of 30 banks representing 10 countries according to GMM technique. For the first and second hypotheses, we can reject the null hypothesis and accept the alternative one. A robustness check has been conducted by examining the whole effect, as shown from Table IV.

Results indicate that banks' asset quality measured by Average change of nonperforming loans ratio (NPL) seems to be sensitive to Covid-19 spread, measured by Average cases of COVID-19 per 100,000 (CAS). Besides, findings support the effect of social distancing, measured by each of average staying at residential (RES) and average social distancing for retail-recreation (RET).

It's important to pinpoint that results don't support the effect of each of average deaths of Covid-19 and average social distancing for workplaces, residential, grocery

\begin{tabular}{|c|c|c|c|c|c|c|c|c|c|}
\hline Variables & CAS & DEA & WOR & RES & RET & PHA & PAR & TRA & NPL \\
\hline Mean & 5607.136 & 130.9250 & -21.696 & 9.464000 & -26.122 & -3.744 & -2.831 & -26.918 & 0.027142 \\
\hline Median & 2915.835 & 73.96000 & -21.91 & 10.68500 & -25.97 & -6.185 & -13 & -29.455 & 0.020486 \\
\hline Maximum & 28433.73 & 411.1500 & -8.06 & 14.13000 & -13.68 & 14.52000 & 52.13000 & -9.19 & 0.083833 \\
\hline Minimum & 148.9800 & 1.800000 & -31.23 & 2.850000 & -45.49 & -13.19 & -38.92 & -50.23 & 0.004719 \\
\hline Std. Dev. & 8241.113 & 136.8363 & 6.602470 & 3.700447 & 9.509474 & 8.048062 & 29.33144 & 12.96799 & 0.024148 \\
\hline Skewness & 2.124882 & 1.009074 & 0.573561 & -0.47634 & -0.49029 & 1.115687 & 0.468427 & -0.08221 & 1.338920 \\
\hline Kurtosis & 6.373381 & 2.667896 & 2.706979 & 1.868109 & 2.557434 & 3.326770 & 1.961995 & 2.033556 & 3.800506 \\
\hline Jarque-Bera & 36.80024 & 5.229019 & 1.752186 & 2.735949 & 1.446738 & 6.357266 & 2.443938 & 1.201307 & 9.764546 \\
\hline Probability & 0.000000 & 0.073204 & 0.096407 & 0.084622 & 0.085115 & 0.041643 & 0.094649 & 0.08453 & 0.007580 \\
\hline Observations & 30 & 30 & 30 & 30 & 30 & 30 & 30 & 30 & 30 \\
\hline
\end{tabular}
pharmacy, parks and transit stations.

\begin{tabular}{|c|c|c|c|c|c|c|c|c|c|}
\hline & CAS & DEA & WOR & RES & RET & PHA & PAR & TRA & NPL \\
\hline CAS & 1 & & & & & & & & \\
\hline DEA & 0.802382 & 1 & & & & & & & \\
\hline WOR & -0.53107 & -0.68186 & 1 & & & & & & \\
\hline RES & 0.302572 & 0.435001 & -0.56043 & 1 & & & & & \\
\hline RET & -0.66484 & -0.77614 & 0.702063 & -0.69771 & 1 & & & & \\
\hline PHA & -0.25677 & -0.41599 & 0.692358 & -0.69763 & 0.346618 & 1 & & & \\
\hline PAR & -0.25338 & -0.41719 & 0.24802 & -0.72228 & 0.524501 & 0.345441 & 1 & & \\
\hline TRA & -0.12786 & -0.38626 & 0.702798 & -0.55478 & 0.607172 & 0.51022 & 0.379509 & 1 & \\
\hline NPL & 0.828064 & 0.61797 & -0.30046 & 0.067606 & -0.58524 & 0.173136 & -0.2061 & 0.017101 & 1 \\
\hline
\end{tabular}

Source: outputs of data processing using EViews10.

Source: outputs of data processing using EViews10.

\begin{tabular}{|c|c|c|c|}
\hline Item & COVID-19 pandemic Effect & Social Distancing Effect & The Whole Effect \\
\hline \multirow{2}{*}{$\mathrm{C}(1)$} & 0.016032 & -0.001907 & 0.000879 \\
\hline & $(0.005018)^{* *}$ & $(0.021089)$ & $(0.016302)$ \\
\hline \multirow{2}{*}{ CAS } & $-2.74 \mathrm{E}-06$ & & $-2.05 \mathrm{E}-06$ \\
\hline & $(7.40 \mathrm{E}-07)^{* * *}$ & & $(6.04 \mathrm{E}-07)^{* * *}$ \\
\hline \multirow{2}{*}{ DEA } & $-2.68 \mathrm{E}-05$ & & $-4.58 \mathrm{E}-05$ \\
\hline & $(4.45 \mathrm{E}-05)$ & & $(4.89 \mathrm{E}-05)$ \\
\hline \multicolumn{4}{|l|}{ WOR } \\
\hline \multirow{2}{*}{ RES } & & -0.004146 & \\
\hline & & $(0.002334)^{*}$ & \\
\hline \multirow{2}{*}{ RET } & & -0.002472 & -0.001129 \\
\hline & & $(0.000823)^{* *}$ & $(0.001122)^{*}$ \\
\hline \multicolumn{4}{|l|}{ PHA } \\
\hline \multicolumn{4}{|l|}{ RAR } \\
\hline \multicolumn{4}{|l|}{ TRA } \\
\hline R-squared & 0.633902 & 0.780780 & 0.893217 \\
\hline Durbin-Watson stat & 1.767426 & 0.860918 & 1.767426 \\
\hline
\end{tabular}

TABLE IV: IMPACT OF COVID-19 PANDEMIC AND SOCIAL DISTANCING ON NPL USING GMM TECHNIQUE

Source: outputs of data processing using EViews10. 


\section{SUMMARY AND CONCLUSION REMARKS}

This paper aims at testing the significance of each of Covid-19 pandemic and social distancing on banks' asset quality, using a sample of 30 banks representing 10 countries according to GMM technique. Data have been collected from the World Health Organization during 2020. The research covers 10 countries (Egypt; Saudi Arabia; Indonesia; Germany; France; Russia; India; Mexico; South Korea and Nigeria) where 3 banks have been investigated from each country.

Results indicate that banks' asset quality measured by Average change of nonperforming loans ratio seems to be sensitive to Covid-19 spread, measured by Average cases of COVID-19. Besides, findings support the effect of social distancing, measured by each of average staying at residential and average social distancing for retailrecreation. It's important to pinpoint that results do not support the effect of each of average deaths of Covid-19 and average social distancing for workplaces, residential, grocery pharmacy, parks and transit stations.

\section{APPENDIX}

THE RESEARCH SAMPLE

\begin{tabular}{ccc}
\hline No. & Country & Bank \\
\hline 1 & Egypt & Commercial International Bank \\
2 & Egypt & Credit Agricole - Egypt \\
3 & Egypt & National Bank of Egypt \\
4 & France & BNP Paribas \\
5 & France & Crédit Coopératif \\
6 & France & TARGOBANK AG \\
7 & Germany & DekaBank Deutsche Girozentrale \\
8 & Germany & Deutsche Bank AG \\
9 & Germany & NRW BANK \\
10 & India & Axis Bank \\
11 & India & Bandhan Bank \\
12 & India & Catholic Syrian Bank \\
13 & Indonesia & Bank Danamon \\
14 & Indonesia & Bank Negara \\
15 & Indonesia & Bank Rakyat (BRI) \\
16 & Mexico & Banamex \\
17 & Mexico & BBVA Bancomer \\
18 & Mexico & Santander Mexico \\
19 & Nigeria & Access Bank \\
20 & Nigeria & Guaranty Trust Bank (GTBank) \\
21 & Nigeria & Zenith Bank \\
22 & Russia & Alfa Bank \\
23 & Russia & PromSvyaz Bank \\
24 & Russia & VTB Bank \\
25 & Saudi Arabia & Al Rajhi Bank \\
26 & Saudi Arabia & Banque Saudi Fransi \\
27 & Saudi Arabia & Riyad Bank \\
28 & South Korea & KB Financial Group \\
29 & South Korea & NongHyup Financial Group \\
30 & South Korea & Shinhan Financial Group \\
\hline & & \\
& &
\end{tabular}

\section{REFERENCES}

[1] Alber, N. \& Refaat, A. (2020). The Effects of Covid-19 Spread on the Egyptian Stock Market Sectors: Winners and Losers across Time.pdf, Available at: http://ssrn.com/abstract $=3741179$.

[2] Alber, N. \& Dabour, M. (2020). The Dynamic Relationship between FinTech and Social Distancing under COVID-19 Pandemic: Digital Payments Evidence, International Journal of Economics and Finance, 12 .(11)

[3] Alber, N. \& Saleh, A. (2020). The Impact of Covid-19 Spread on Stock Markets: The Case of the GCC Countries, International Business Research, 13.(11)
[4] Alber, N. (2020 a). The Effect of Coronavirus Spread on Stock Markets: The Case of the Worst 6 Countries. Available at: http://ssrn.com/abstract=3578080.

[5] Alber, N. (2020 b). Finance in the time of Coronavirus during 100 Days of Isolation: The Case of the European Stock Markets, Available at: http://ssrn.com/abstract=3631517.

[6] Angklomkliew, S., George, J., \& Packer, F. (2009). Issues and developments in loan loss provisioning: the case of Asia. BIS Quarterly Review.

[7] Arafa, A. \& Alber, N. (2020). The Impact of Coronavirus Pandemic on Stock Market Return: The Case of the MENA Region. International Journal of Economics and Finance, 12 (12).

[8] Cortavarria, L., Dziobek, C. H., Kanaya, A., \& Song, I. (2000). Loan review, provisioning, and macroeconomic linkages. International monetary fund.

[9] Dilba, Denis (2020). NPL trading in transition, EOS explore 2/2020, 34-35.

[10] Djankov, S., \& Zhang, E. (2021). As COVID rages, bankruptcy cases fall, 4 February (VoxEU).

[11] Gourinchas, P. O., Kalemli-Özcan, Ș, Penciakova, V., \& Snder, N. (2020). Covid-19 and SME failures (No. w27877). National Bureau of Economic Research.

[12] Haselmann, R., \& Tröger, T. (2021). When and how to unwind COVID-support measures to the banking system? (No. 83). SAFE White Paper.

[13] Kashyap, A., \& Hoshi, T. (2008). Will the US Bank Recapitalization Succeed? Lessons from Japan. NBER Working Paper, (1440).

[14] Kasinger, J., Krahnen, J. P., Ongena, S., Pelizzon, L., Schmeling, M., \& Wahrenburg, M. (2021). Non-performing loans-new risks and policies? NPL resolution after COVID-19: Main differences to previous crises (No. 84). SAFE White Paper .

[15] Mongey, S., Pilossoph, L., \& Weinberg, A. (2020). Which workers bear the burden of social distancing policies? (No. w27085). National Bureau of Economic Research .

[16] Moreno, A., S. Ongena, A. Ventula Veghazy and A. Wagner (2020): The global financial seizure and the COVID-19 pandemic, in: Billio, M. and S. Varotto (eds) A new world post COVID-19: lessons for business, the finance industry and policy makers, Venice: Fondazione Università Ca' Foscari, 23-34.

[17] Wagdi, O., \& Rabie, R. (2021). The Impact of COVID-19 Pandemic on Business Activities and Lifestyle: Evidence from Egypt. Annals of the Romanian Society for Cell Biology, 25(4), 10392-10406.

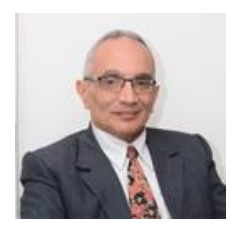

Dr. Nader Alber is a Professor of Finance and the head of the department. He has more than three decades of experience in teaching, research and academic administration. Dr. Nader has participated and presented research papers in 11 international conferences held in France, Italy, Greece, Cyprus, Turkey, and Malaysia. Moreover, he has published more than 45 papers. Dr. Nader has participated in supervision and discussion of more than 300 researches submitted for MSc, PhD, MBA and DBA degrees. He is interested in research areas that are related more specifically to financial modeling, banking performance, financial stability, and banking efficiency.

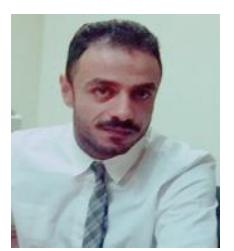

Mohamed Dabour, PhD candidate at Ain Shams University - held MSc from Helwan University, interested in AI and FinTech area of research. More than ten years' experience in Banking industry, and part time as finance \& Investment teaching assistant. 